\title{
Input of Communication Studies and Pattern Reform of Journalism Education in China
}

\author{
WANG Wenxiao ${ }^{1, a}$ \\ ${ }^{1}$ Public Administration, Beijing City University, Beijing 100191,China \\ awangwenxiao2013@163.com
}

Keywords: Journalism education, education pattern

\begin{abstract}
This passage is to analyze the present situations of education concept, course setting and team of teachers in journalism education of our country. In terms of the problems of present journalism education of China, drastic measures will be put forward. In addition, the topic of how to establish a journalism education pattern which matches the media market is also to be discussed so as to bring more enlightenment to news educators of our country.
\end{abstract}

\section{Introduction.}

Communication study is a new subject which has risen in the 1940's. In the 1960's, it became a prominent subject being popular all over Northern America and Western Europe. Many universities created communication or mass communication subject and rename Journalism Department to Communication Department or Mass Communication Department, turning journalism study into communication study and setting up new developing goals, course system and teaching steps.

How can communication study enrich journalism and transform the silent condition of journalism? Why communication study is able to enrich journalism study depends on the relationship between them.

\section{Information, media and audiences.}

To begin with, information is the central concept of communication study and social information is the natural target of communication research. News is the central concept of journalism and the logical starting point of journalism research. News is part of information and interconnected with information. This kind of compatriotic research content will be a essential requisite of the integration of journalism and mass communication.

Secondly, journalism rises with the appearance of news spreading media, which regards newspaper media as the research target at the very beginning. "media research" is one of the important points of communication research. However, it researches not only news media, but also all mass communication media. That is to say, identical parts are involved within journalism and communication study.

Thirdly, audiences. "Audiences” in mass communication are called " readers" or " listeners" in journalism. Although "audience” and "reader” play different roles in their own subject research, what they deliver are naturally similar.

The fact that communication study is able to transform the "no course to teach" condition of journalism education counts on the differences between them. Communication study is able to make up a great many flaws of journalism.

\section{Differences between communication study and journalism study.}

First of all, attributes are different. Journalism is part of humanism and an applicable subject involved in humanism while communication is part of socialism and a behavior subject of socialism. Humanism cares about humanity, expresses the terminal care for mankind themselves and focuses on mankind's values of living and mental appearance such as faith, emotion, morality and beauty. And its standpoint is subjective. Therefore, journalism is a subject instead of science. Journalism's transformation into communication is able to add certainty of journalism theory.

In addition, logical starting points researched are different. As mentioned before, journalism 
starts with news as a logical starting point, paying more attention to news collection, news writing, news processing as well as internal operation of news media including media functions, features and principles, which defines the technological content of journalism. Communication starts with the communicating phenomenon of mankind society, giving priority to the interaction between media and society, society's impact on media and media's influence on society.

Last but not least, research methods are different. As mentioned before, journalism is a humanistic subject whose methods are of quality and logic. Communication is a subject of socialism and its methods are mainly of quantity and evidence. The former contain obvious subjectivity, politics and ideology. On the contrary, the latter is objective, accurate and easy to operate. So-called objectivity mainly refers to that collection of material and interpretation of data are based on facts, not including personal opinions. So-called accuracy refers to that concepts involved in theoretic topics are all strictly defined and can be measured through concept index. Operablity mainly means that there are some specific procedures and strict operating ways. Moreover, these procedures and methods can only be operated by professional talents. Scientific ways for communication research not only allow communication study to have its own theoretic system, but also mature subject system.

\section{Characteristics of communication study in China.}

What is special when China brings in and studies communication? To draw a conclusion with one word, journalism research and development are powers of communication's bringing in and researching. In the West, the founders of the science of communication are not journalism scholars and even journalists, but political scientists, sociologists and psychologists. But in China, those who bring in communication studies from the west to China are basically journalism scholars and pragmatic journalism people.

After reform and opening up to the outside, China's mental and physical civilization have developed at an unprecedented speed. Favorable political and economic situations require the research of journal study and the development of journal cause to achieve new breakthroughs. To do well in the research of journal study, we must emancipate our thoughts and look into the future with a pair of sharp eyes.

News spreading media not only plays a vital role in widely spreading information, but also entertaining the public, gradually becoming a subsystem in the entire social spreading system. However, the traditional journal study theory is not fit for it. Thus, people turn to the communication study.

From 1994 to 1998, China's communication experienced a climax. As an old saying goes, Stones form other hills can serve to polish jade. It is the idea of many communication researchers to put in western communication study and absorb reasonable things from it to transform Chinese traditional journal study. In 1984, Hewei, a renowned professor, wrote a passage which come up with some valuable ideas. Communication study has drawn an amount of attention from all over the world and people from our country are also researching it and setting related majors. It is being at a phase of introducing, understanding and researching. Journal study never researches news spreading cause as a whole and seldom investigate the readers, listeners and audiences. Let's first set aside these comments but express our gratitude to his reminding us of doing the comparison research of both journal study and communication study. We are supposed to first make sure of their similar and different features and further analyze the internal process with materialist dialectics, revealing its evolving laws to know communication study in a correct way.

After DengXiaoping's southern tour speech, Chinese people's thoughts have been largely emancipated. Socialist market economic system is still restricted to the outside, which obviously doesn't match the current journal cause.

In the midst of 1990's, Chinese communication study experienced another climax. This climax demonstrated not only the systematic introduction of communication study, but also the preparation to establish communication study system with Chinese characteristics, especially applying communication theories and methods to transform Chinese traditional journal study, creating a new 
subject named “journalism communication studies”.

The idea of news communication studies is a symbolic result of Chinese communication research. In the west, journalism is less focused compared with communication studies and mass communication studies. On the contrary, in China, journalism studies keep pace with communication studies. Communication studies develop on the basis of journalism studies. In other words, journalism studies have exerted great influence on communication studies.

In China, "journalism communication studies" is a new subject due to the integration of "journalism study" and "communication study". Therefore, it is involved neither in the traditional journalism study nor the original communication study.

\section{Re-identification of journalism education notion.}

As mentioned earlier, the traditional journalism education training objectives are simple and clear: mainly to newspapers, radio, television and other traditional media, mining , writing, editing, broadcasting needs of their work, through the expertise teaching, vocational skills training cultivating news media talents. With the advent of the information society, dissemination of technological advances and the fourth medium rise, the situation becomes more complicated.

On the one hand, as the technology content of the media increases, relying on a mouth and a pen can't make reporters and editors. On the other hand, a comprehensive and multi-dimensional Internet makes information spreading activity both colorful and confusing. At the same time, with the progress of society as well as the establishment of the mass concept, the integration of mass communication industry and the telecommunications industry will become an indisputable fact .

Chinese journalism education cause will be faced with a sharp challenge which requires journalism concept to re-identify itself.

In a broad mindset, it is necessary to combine humanities, social sciences and telecommunication, creating an atmosphere blended with both art and science. Besides, it is also indispensable to build up an atmosphere of scientific education and skill training to cultivate more and more researchers and pragmatic people for journalism study cause.

So-called compound talents are different from what have been mentioned in the earlier time, such as eclectic reporter, expertise reporter, writing reporter, professional reporter and all-around reporter. There are three facets contained in "compound". Firstly, it should be three-dimensional, including not only profound cultural foundation and a solid foundation of communication theory , but also modern communication skills. Secondly, it should be highly energetic, focusing collection, editing and processing in one. Thirdly, it should be multi-faceted, versatile in journalism and communication. This doesn't mean a person is supposed to be good at everything, but proficient in one and skillful in several aspects.

\section{New discovery of educational ways.}

Educational ways change with the transformation of educational theories. Chinese journalism education in the traditional mode, is a single- discipline education, which emphasizes on humanities education. Although in the mid- 1980s, many schools' news subjects in teaching carried out some reforms, creation of higher mathematics, communication studies, and some computer courses, but it is still a humanistic teaching system. Huazhong University of Science News and Information Communication School, in the 1990s, made a big span crossing pattern. In order to satisfy the great needs of compound talents, This university gives priority to both journalism study and communication study, transforming from single education to multi-subject education. Students not only need to study courses such as history and philosophy, but also need to receive behavior science education involving socialism, psychology and politics. In the meantime, natural science like telecommunication and computer are also required to learn.

\section{Summary.}

Early Chinese journalism education basically applies U.S. educational philosophy and school mode. With the social development, Chinese journalism education twists and turns, drawing on the 
U.S. model of development and constantly learning the elements of various civilizations. Thus forming a civilization which has its own connotation local journalism education is essential. Although Chinese journalism education made great progress, in fact, there are many drawbacks existing in journalism education. Therefore, how to make journalism education to be adapted to media market is the urgent need to break through the current difficulties of journalism education .

The road ahead is long and we have more to do. As the society is developing at an unprecedented speed, we ought to keep pace with time and make every effort to assure that we are not lagged behind by times.

Therefore, it is a must for us fulfill our responsibilities and face up with the coming challenges with courage.

\section{References}

[1]CaiYuanpei, Speech of the Establishment of News Researching Association in Peking University[N]. Daily Journal of Peking University, 1918-10-16.

[2]ChenChangfeng, Sino-US Journalism Education Legacy[M]. China Broadcasting and Television Publishing House, 2006: 70

[3]Huangli, Current Situations of US Journalism Education[J]. Contemporary Spreading, 2003(6).

[4]Libing, Journalism Education[J], Modern Listening and Watching, 2007(4).

[5]Media Education: half prosperity, half anxiety[EB/OL]. http://news.xinhuanet.com/new media/2005-04/30/content_2898309.htm,2005,4-30/2008,5-30. 